\title{
Development and evaluation of 3D virtual tours as a cognitive basis of Chemistry laboratories at UTSV
}

\author{
Desarrollo y evaluación de recorridos virtuales 3D como base cognitivo de los \\ laboratorios de Química en la UTSV
}

GOMEZ-MANUEL, Esbeidy†*, DOMINGUEZ-CAMPOMANES, Margarita, ORTIZ-HERNÁNDEZ, Elena and KATT-MORALES, Luz Alondra

Universidad Tecnológica del Sureste de Veracruz, Career of Engineering in Information Technology

ID $1^{\text {st }}$ Author: Esbeidy, Gómez-Manuel / ORC ID: 0000-0003-0765-3402, Researcher ID Thomson: G-2859-2019, arXiv Author ID: 2419916, CVU CONACYT ID: 599053

ID $1^{\text {st }}$ Co-author: Margarita, Dominguez-Campomanes / Researcher ID Thomson: G-5015-2019, arXiv Author ID: 2635670, CVU CONACYT ID: 947280

ID $2^{\text {nd }}$ Co-author: Elena, Ortíz-Hernández / ORC ID: 0000-0003-0959-8435, CVU CONACYT ID: 1150084

ID $3^{\text {rd }}$ Co-author: Luz Alondra, Katt-Morales / ORC ID: 0000-0002-9982-8718, arXiv Author ID: 2417152, Researcher ID Thomson: S-6606-2018, CVU CONACYT ID: 412698

DOI: $10.35429 /$ JCSI.2021.20.7.5.9

Received July 18, 2021; Accepted October 30, 2021

\begin{abstract}
The objective of this article is to develop virtual tours in three dimensions (3D) of the Chemistry laboratories of the Technological University of the Southeast of Veracruz (UTSV). For its progress, it was carried out: analysis, selection, training, design, development and integration of software and hardware tools. The same ones that were necessary for the development of virtual reality on 3D modeling of the General Chemistry, Instrumental Analysis and Chemical Plants laboratories, achieving a product that would allow university students to be approached virtually, and thus be able to know the spaces and devices located in each laboratory, where it presents the description of the operation of each of the equipment, by means of multimedia effects accompanied by an avatar within the virtual tour. Finally, the final result was evaluated with a group of students with the support of the Chemistry teachers and knowledgeable about the laboratory spaces, where the degree of acceptance and perception was obtained as a consequence through a survey carried out.
\end{abstract}

Virtual Tour, 3D Modeling, Chemistry Labs

\begin{abstract}
Resumen
El presente artículo tiene como objetivo desarrollar recorridos virtuales en tercera dimensión (3D) de los laboratorios de Química de la Universidad Tecnológica del Sureste de Veracruz (UTSV). Para su progreso se realizó: análisis, selección, capacitación, diseño, desarrollo e integración de las herramientas de software y hardware; mismos que fueron necesarios para el desarrollo de la realidad virtual sobre modelados 3D de los laboratorios de Química General, Análisis Instrumental y Plantas Químicas, logrando un producto que permitiera aproximar de manera virtual a los estudiantes universitarios, y así poder conocer los espacios y aparatos ubicados en cada laboratorio, en donde presenta la descripción del funcionamiento de cada uno de los equipos, por medio de efectos multimedia acompañados de un avatar dentro del recorrido virtual. Por último, se evaluó el resultado final con un grupo de estudiantes con apoyo de los docentes de Química y conocedores de los espacios de los laboratorios, en donde se obtuvo como consecuencia el grado de aceptación y percepción mediante una encuesta realizada.
\end{abstract}

Recorrido Virtual, Modelado 3D, Laboratorios de Química

Citation: GOMEZ-MANUEL, Esbeidy, DOMINGUEZ-CAMPOMANES, Margarita, ORTIZ-HERNÁNDEZ, Elena and KATT-MORALES, Luz Alondra. Development and evaluation of 3D virtual tours as a cognitive basis of Chemistry laboratories at UTSV. Journal of Computational Systems and ICTs. 2021. 7-20: 5-9

\footnotetext{
*Correspondence to Author (e-mail: esbeidy.gomez@utsv.edu.mx)

$\dagger$ Researcher contributing as first author.
} 


\section{Introduction}

Every day new challenges arise when transmitting the knowledge of different areas, having the task of looking for digital means to develop and apply new information technologies (IT). Rodríguez, AM, Marín, C., and Munévar Molina RA (2013) Indicates that for this reason advanced education on par with technology, and takes advantage of the elements that it offers to bring man closer to a similar reality in which he lives, thereby achieving a better understanding of the knowing subject and in some cases a transformation and interpretation of it. Araque, I., Montilla, L., Meleán, R., Arrieta, X. (2018) Describes that, with the appearance of ICT (Information and Communication Technologies), various strategies are included that combine methods, techniques and means available to the teacher, who has the responsibility to design and implement in favor of learning.

Resulting in the development of different virtual learning environments, having as an inclination in the construction and acquisition of competences through teaching-learning. MartínGutiérrez, J., Mora, CE, Añorbe-Díaz, B. and González-Marrero, A. (2017) Mentions that the construction and visualization of alternative realities requires hardware and software powerful enough to create an immersive experience realistic. Posada Calderón, S., Monsalve Suárez, Y., \& Mateus Santiago, S. P. (2019) Refers that Virtual Reality is conceived as a simulated reality, which is built with computer systems through the use of digital formats. The present work aims to develop a 3D virtual tour of the Chemistry laboratories of the UTSV, which serves as a support for a digital approach without many walls that prevent knowing the area chosen for their professional training

\section{Methodology to be developed}

In the development of the 3D virtual tour, it was based on the Scrum agile development methodology, allowing assigning tasks to elaborate and deliver in short times, measuring its progress with the end user. Likewise, to have the information of the 3D objects presented from the laboratories, it was necessary to carry out the field investigation.
The materials favor the presentation of the contents in a different, striking, non-linear and motivating way, which facilitates the integration of text with images, video, audio, animations and software elements, and offers a range of more creative actions, combined with innovation in the way of its description or approach, elements that when combined can impact the learning process of students. The steps that were carried out for the 3D virtual tour of the Chemistry laboratories of the UTSV are presented.

\section{A. Development of the virtual tour}

\section{3D modeling}

To start with the edition of the virtual tour, it was necessary to have the $3 \mathrm{D}$ designs of the Chemistry laboratories with their respective instruments. Each object was modeled in SketchUp software.

\section{Recording 3D tour scenes}

Scenes were obtained in the software where the designs of the 3D objects were made, then they were saved and later exported to the official Kubity website to convert it into Virtual Reality (VR) and record the route.

\section{Avatar Design and Animation}

In the first instance, a sketch of the avatars (male and female version) was made considering that they were to the liking of the users. With the use of basic design tools, in this case it was Paint, the respective corrections were applied, adding and removing various details from the initial drawing to result in a base on which a color palette can be applied. The different movements of the speaking and blinking gestures were then illustrated. At the end of the editions of the images, they were exported to the Animated Gif Maker program, where it allows us to dock them to create the gif, and assign a duration time to each image and raise the resolution quality of the same to obtain a result of more fluid animation.

\section{Video introduction (intro) design}

In this process, images, sound, text and animation were used, in order to create a material that when reproduced is attractive to viewers. 
The color tones were combined and the corresponding texts were added, using them as transparent images, to make it easier to place a presentation and exit animation on each text. Likewise, a fragment of the videos and promotional music of the UTSV was used.

\section{Dialogue recording}

The names and the functionality of each object modeled in 3D from the Chemistry laboratories was investigated, obtaining a guide. Thus, the voices with a suitable tone for the listener were also selected, to later act as the voice of each avatar, either female or male, ending with the recording depending on the object to be described.

\section{Video editing}

The video editing process was selected an appropriate open access software. Then it began with the selection of what was created previously: recording of scenes of the tour, the gifs of the avatars, intro of the video and the recording of the dialogues. The first thing was to place the created intro and join the video of the tour together with the background music. Then it was to place the dialogues that were recorded for the avatars according to the visualized scene, since from these the gifs would be placed to know exactly the duration of these in the video. This process was repeated in each of the audios until reaching the end of the video where the credits were later placed and the project was saved, exporting the video to an .mp4 format.

\section{B. Video evaluation}

The steps for the acceptance test of the 3D virtual tour video of the laboratories of the Chemistry career. They were the following ones:

Plan the test: where the steps and times to carry out the survey were defined. The questions to be asked, the quantity, type of instrument and the means to apply it were also analyzed. The Likert scale was selected to measure the reactions of the end users according to the responses. Likewise, the group of students and teachers of the Chemistry career was managed to apply the evaluation of the final product.
- Design the instrument: once the questions had been chosen and a response style applied, they proceeded to capture them and choose a suitable heading design, in this phase the platform most used by the students and teachers of the UTSV was chosen for the design of the instrument to implement.

- $\quad$ Execute the instrument: The link to the survey and the videos was shared with the teacher responsible for the groups in the Chemistry area, according to the dates previously agreed upon during the administration.

- $\quad$ Analysis of the results: Once the online evaluation instrument has been applied, it is evaluated according to the chosen answers, where the results of each question are shown.

\section{Results}

This section presents the 3D virtual tour, a walk where spaces designed in 3D combined with multimedia effects are presented, which allow to have a vision and approach to live an experience of reality, collaborating in the development of professional skills. The laboratories that were designed with a 3D tour were: General Chemistry, Instrumental Analysis and Chemical Plants.

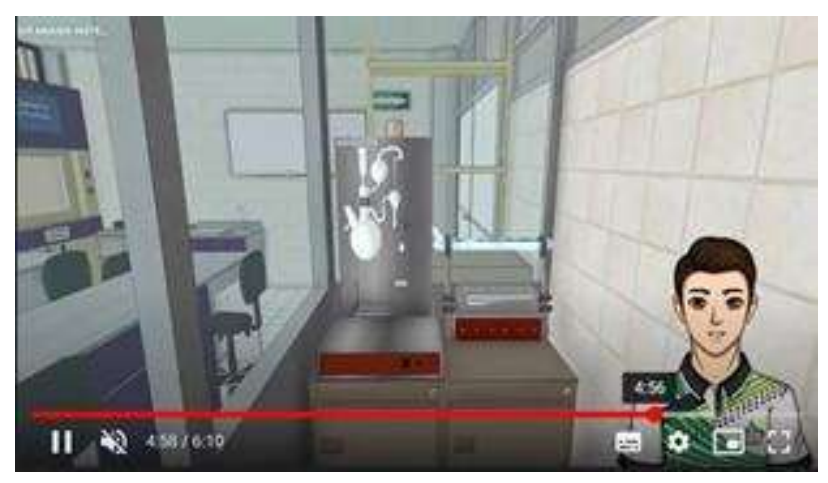

Figure $13 \mathrm{D}$ Lab.QG Virtual Tour

Own

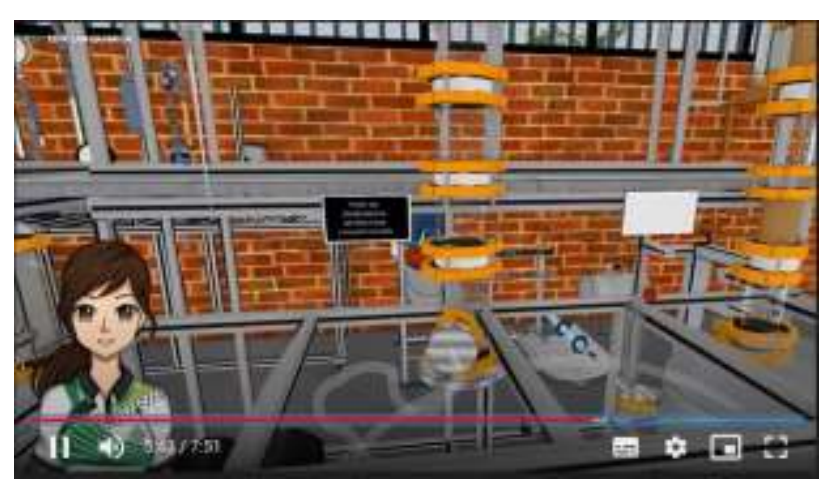

Figure 2 3D Virtual Tour Lab.PQ

Own

GOMEZ-MANUEL, Esbeidy, DOMINGUEZ-CAMPOMANES, Margarita, ORTIZ-HERNÁNDEZ, Elena and KATT-MORALES, Luz Alondra. Development and evaluation of 3D virtual tours as a cognitive basis of Chemistry laboratories at UTSV. Journal of Computational Systems and ICTs. 2021 


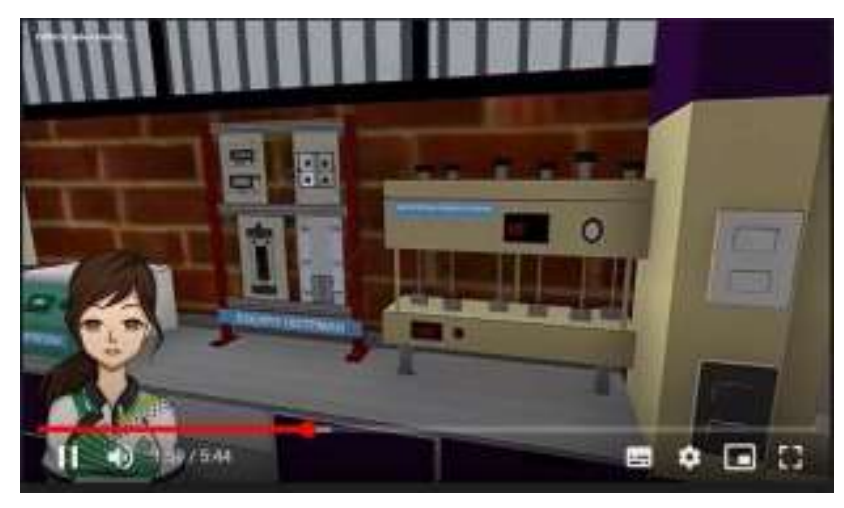

Figure 3 3D Lab.AI Virtual Tour Own

At the end of viewing the course through the videos with a $3 \mathrm{D}$ virtual tour, they were asked to carry out the survey through an online form, where they selected an answer such as: totally disagree, disagree, agree and totally agree. It was applied to a group with 25 students from the Chemistry career and questions regarding the context of the content of the tour, such as: Is the 3D virtual tour video suitable for getting to know the Industrial Chemistry laboratories at UTSV for the first time? Is the implemented tone of voice adequate and acceptable for understanding? Is the information presented in the video of the virtual tours of the Chemistry laboratories clear, precise and understandable? Is the 3D Design displayed in the Virtual tour allows you to experience a meaningful learning? Do you consider that the video would be a support for the learning process of the laboratories? The video visualizes imagination? The video visualizes creativity? The video visualizes design? The quality of the tour virtual is generally acceptable? Comments or Suggestions.

Focusing attention on the following results: $92 \%$ of those surveyed believe that the $3 \mathrm{D}$ virtual tour video is suitable for getting to know the Industrial Chemistry laboratories at UTSV for the first time.

All the respondents believe that the information presented in the video of the virtual tours of the Chemistry laboratories is clear, precise and understandable.

$96 \%$ of those surveyed consider that the virtual tour through 3D Design allows them to experience significant learning since it serves as support in the learning process of the chemistry laboratories of the UTSV.
In general, the comments and opinions received refer to considering that the tour offers a visual field of how the learning will be obtained, along with the quality of the service when assisting in person in the realization of the practices. Another aspect considered is the achievement of cognitive development in students, since derived from the application of virtual reality on $3 \mathrm{D}$ modeling, it was possible to obtain results that show more interest and the possibility of acquiring significant learning derived from the conditions that are presented to you for understanding the information. On the other hand, it allows the teacher to privilege his role as a learning facilitator, focusing on the interests and possibilities of the student so that learning is comprehensive and according to the different styles and channels.

\section{Gratitude}

To the Universidad Tecnológica del Sureste de Veracruz, the Rector, Academic Director, directors, professors and students of the Chemistry and Information Technologies career, for all the collaboration and support received.

\section{Conclusions}

It is concluded that this project will provide teachers and students with a support tool in teaching and motivation in the classroom, improving the quality of learning, being a benefit for the institution by applying this innovative strategy with quality resources and technologies. . Taking into account that there are all the necessary technological tools to carry out this project, its feasibility is demonstrated, since the video enriched with virtual reality and 3D modeling is a tool to be used inside and outside the classroom, becoming a very useful resource to carry out tasks and reinforce the topics taught by the teacher, since they not only allow students to capture the interest of the students in a new way in all kinds of subjects, but also turn the hours in the classroom into a more fun experience and encourages immersive learning, that is, through the experience of each student, achieving a greater educational impact. 


\section{Referencias}

Alvarez Alvarez A. y Cabrera Ramos J. F. (2020). Requerimientos para el diseño de la experiencia de inmersión en laboratorios virtuales. Kepes, 17(22), 277 - 299. https://doi.org/10.17151/kepes.2020.17.22.11

Araque, I., Montilla, L., Meleán, R. y Arrieta, X. (2018). Entornos virtuales para el aprendizaje: una mirada desde la teoría de los campos conceptuales. Góndola, enseñanza y aprendizaje de las ciencias, 13(1), 86-100. http://doi.org/10.14483/23464712.11721

Bareño Alarcón, E. (2021). Herramienta multiplataforma para la evaluación comparativa de wayfinding en ambientes virtuales.

[Tesis].

http://hdl.handle.net/20.500.12209/16518

Buitrago-Pulido, R. D. (2015). Incidencia de la realidad aumentada sobre el estilo cognitivo: caso para el estudio de las matemáticas. Educación Y Educadores, 18(1), 27-41. https://doi.org/10.5294/edu.2015.18.1.2

Izquierdo Pardo, J. M., Izquierdo Lao, J. M. y Pardo Gómez, M. E. (2020). Modelos digitales $3 \mathrm{D}$ en el proceso de enseñanza-aprendizaje de las ciencias médicas. MEDISAN, 24(5), 10351048.

http://scielo.sld.cu/scielo.php?script=sci_arttext \&pid=S1029-30192020000501035

Martín-Gutiérrez, J., Mora, C. E., Añorbe-Díaz, B. y González-Marrero, A. (2017). Virtual Technologies Trends in Education. Eurasia Journal of Mathematics, Science and Technology Education, 13(2), 469-486. https://doi.org/10.12973/eurasia.2017.00626a

Posada Calderón, S., Mateus Santiago, S. y Monsalve Suárez, Y. (2019). Entorno virtual 3D de la tabla periódica como apoyo en la educación de la química. Revista Politécnica, 15(30), 4154. https://doi.org/10.33571/rpolitec.v15n30a5

Quinche, J. C., y González, F. L. (2011). Entornos Virtuales 3D, Alternativa Pedagógica para el Fomento del Aprendizaje Colaborativo y Gestión del Conocimiento en Uniminuto. Formación universitaria, 4(2), 45-54. https://dx.doi.org/10.4067/S0718-

50062011000200006
Rodríguez, A. M., Marín, C., y Munévar Molina R. A. (2013). El papel de la Interactividad en el Desarrollo de los Procesos cognitivos. Revista Educación y Desarrollo Social, 7(2), 98-107. https://doi.org/10.18359/reds.683

Sánchez Núñez, E. A. (2018). El video como herramienta de apoyo en la educación superior. [Tesis]. http://repositorio.uta.edu.ec/jspui/handle/12345 $6789 / 27391$ 